\title{
Landslides susceptibility in central part of Albanian coast
}

\author{
Shkëlqim DAJA, Polytechnic University of Tirana, Albania,daja_s@yahoo.com \\ Çerçis DURMISHI, Polytechnic University of Tirana, Albania, cecodurmishi@yahoo.com \\ Agim SINOJMERI, Polytechnic University of Tirana, Albania, sinojmeri@yahoo.com \\ Shaqir NAZAJ, Polytechnic University of Tirana, Albania, shnazaj@yahoo.com
}

\begin{abstract}
In Albania, landslides are one of the most important natural hazards. In the last few years, landslides damaged buildings, destroyed farming lands and roads etc. For this reason, the regional landslide susceptibility assessments have crucial importance for the landslide prone areas of Albania.

The assessment of the landslide susceptibility is conducted by direct mapping techniques, considering the topography, geomorphology, lithology hydrogeology, earthquakes, anthropogenic actions, rainfalls, erosion, and also the distribution and the characteristics of the phenomena in the area.

The zoning map of the area based on their susceptibility to landslide risk was compiled. Five levels of susceptibility are carried out in Durresi bay (central part of Albanian coast): high, medium-high, medium, medium-low and low risk.

The high and medium-high susceptibility zones, in entire areas under study are controlled by slope inclination. But frequently, high and medium high susceptibilities, for similar geological settings, are situated also in gentle slopes, due to the inappropriate anthropogenic action.

This map reveals very useful as a preliminary work in urban planning and technical preventative measures.
\end{abstract}

Keywords: Landslides, susceptibility maps, slope stability, Durres, Albania

\section{Introduction}

During a period of heavy rainfall, on March 2009, 25 seismic events of magnitude range from 2.2 to 4.4 Richter scale degrees happened. As a consequence, a landslide completely destroyed five buildings and damaged others in Synej, in the central part of Albanian coast. Based on the seismic zoning of Albania, this area is included in the lonian-Adriatic seismic zone, with expected seismic potential of highest magnitude 6-6.4 (Richter scale).

Because in this area it is foreseen an intense development of tourism, especially at the western flank of the anticline, the study of the phenomenon in the entire area was undertaken. The first field investigations showed that the same phenomenon is largely verified in both flanks of the anticline structure.

The analysis of the slope stability in static conditions reveals that the major part of the area results in critical equilibrium state. In this case the slopes of low physical-mechanical properties and already predisposed to failure, may reactivate landslide phenomena, during seismic events, that directly or indirectly interest to the present infrastructure. 


\section{General data for the study area}

The study area is situated in the eastern coast of Adriatic Sea, and is limited by the parallel 4583500, in north, and the one 4557000 (local system of coordinates), in south representing about $17 \mathrm{~km}$ of coast line. The highest elevation in the area is $187 \mathrm{~m}$. The mapping of the landslide susceptibility is focused in two blocks within this area (Fig. 1):

- Block 1 that includes the Durresi town and the hills, north of it, up to Porto Romano, and

- Block 2 that lies south of Durresi Bay and includes the hills of Karpeni, Bagoja to Peqinaj village, in south.

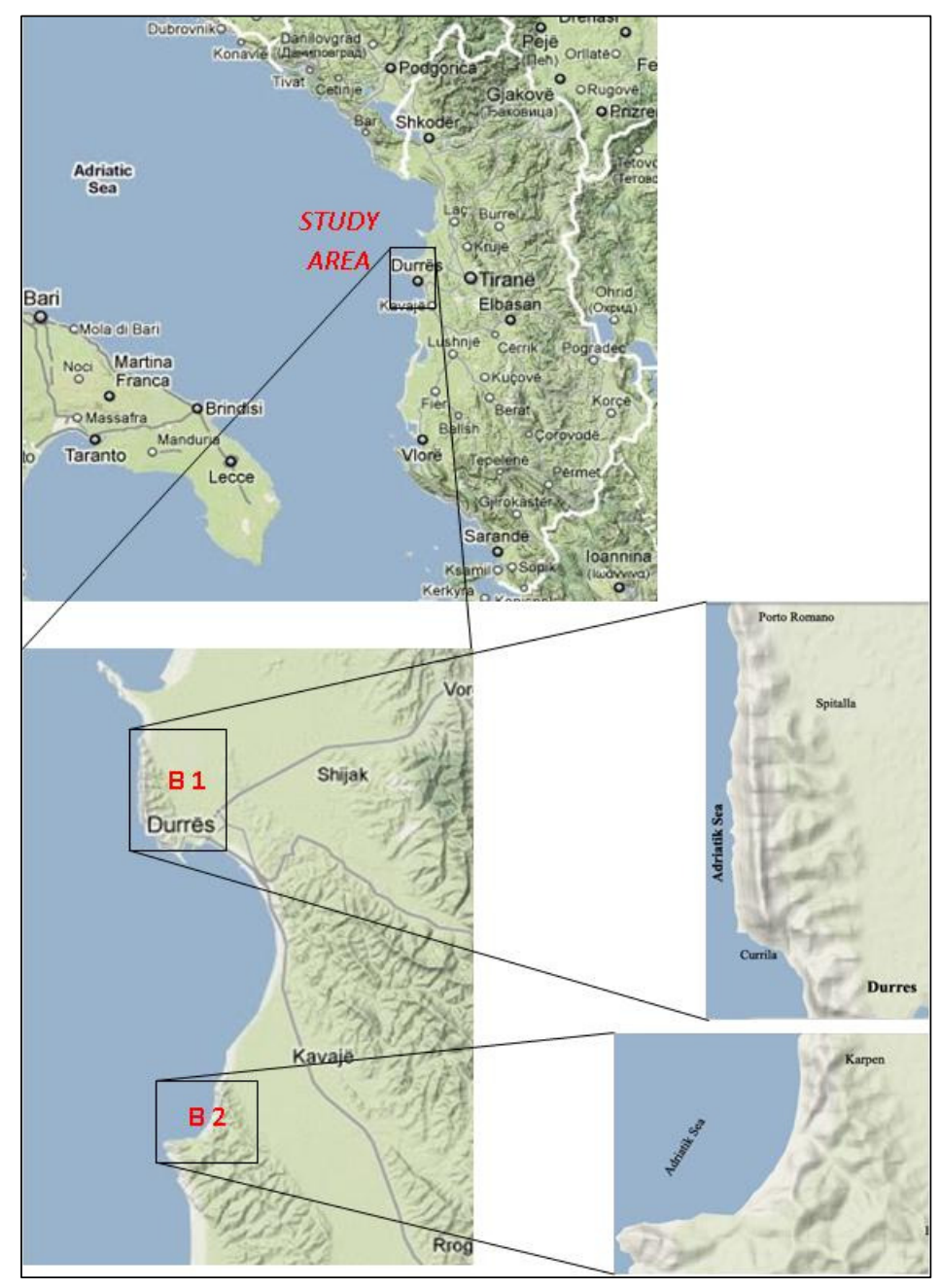

Fig. 1. Location of the study area

\section{Climate}

Mediterranean climate conditions characterise this area. During the summer months, the weather is stable, almost only sunny days which is very important for the daily tourism and for the development of the agriculture.

The average temperatures vary from $8^{0}-9^{0} \mathrm{C}$ in January to $22-23^{0} \mathrm{C}$ in July with an average annual temperature of $16^{\circ} \mathrm{C}$. 
The average of annual rainfalls in the area is $913.2 \mathrm{~mm} / \mathrm{year}$ whereas maximal rainfalls observed in the last 30 years attempt $1200-1500 \mathrm{~mm} /$ year. Most of the rainfalls $(70 \%)$ belong to the half cold part of the year but concentrated during the period October to January.

Table 1. Monthly rainfall $(\mathrm{mm})$

\begin{tabular}{|l|l|l|l|l|l|l|l|l|l|l|l|l|l|}
\hline Station & 1 & 2 & 3 & 4 & 5 & 6 & 7 & 8 & 9 & 10 & 11 & 12 & Mean \\
\hline Durres & 110.6 & 91.4 & 95.2 & 76.3 & 50.8 & 38.7 & 23.9 & 34.8 & 62.5 & 101.1 & 132.9 & 113.0 & 931.2 \\
\hline
\end{tabular}

\subsection{Geomorphology}

The uplifting that began at the end of Pliocene and continues even during Quaternary, has conditioned the exposure of Pliocene deposits leading to a weak lithification process. So, these rocks are easily affected by the weathering and erosion. These processes have originated an erosional relief, susceptible to be affected by the landslides.

The highest height of the study area is $190 \mathrm{~m}$ and the lowest one is the sea level. All the area consist of smooth slopes $10-15^{\circ}$ in east, whereas at the western part the slope dipping vary from $20^{\circ}$ to $35^{\circ}$.

\subsection{Geology of the study area}

The study area is part of the Peri-Adriatic Depression and consists largely by Neogene deposits (Error! Reference source not found.. a).

The Peri-Adriatic Depression in the study area is compiled by Neogene and Quaternary deposits.

The Neogene deposits are widely present, occupying mainly elevated relief, and are represented by Miocene and Pliocene.

The Miocene is represented by Messinian age deposits. Lithologicaly they are composed by clay and sandstone intercalations and evaporites at the top.

The Pliocene deposits consist of two well distinguished units known by the terms: the unit of "Helmesi" $\left(\mathrm{N}_{2}{ }^{\mathrm{h}}\right)$ and the unit of "Rrogozhina" $\left(\mathrm{N}_{2}{ }^{\mathrm{r}}\right)$.

"Helmesi" unit begins with conglomerate and sandstone intercalations, at the base, continuing with siltstone and finishing with massif clays at the top of the sequences. The sandstones (grey - yellow color) are layered $4-8 \mathrm{~cm}$ up to $20-30 \mathrm{~cm}$ thick and weakly cemented. They are fine to medium grained, polymineral and of the quartz-feldspar type. The conglomerates are composed by pebbles of different sizes and shapes. The clays predominate in the sequence. They are grey to blue, soft to compact. The deposits of "Helmesi" unit have a thickness that varies from 500 to $1100 \mathrm{~m}$.

The deposits of "Rrogozhina" unit overlie the massive clays of the top of "Helmesi" unit. These are clastic deposits, sandstones, conglomerates with thin clayey intercalations. The Rrogozhina unit deposits begin with thin sandstone and siltstone intercalations, overlaid by conglomeratic and sandstones sequence up to $4-6 \mathrm{~m}$ thick. The sandstones are fine to coarse grained, polymineral and of quartz - feldspar type. In the conglomerates there are rounded and half rounded pebbles of magmatic and sedimentary rocks. The cement is 
clayey - silty - sandy, and rarely gravelitic. The sandstones and conglomerates of this formation are characterized by inclinated and cross bedding layering.

The Quaternary deposits, in the area, are represented by weathering products. The deluvial deposits are the most frequent type of the Quaternary deposits. Their thickness varies from some meters to $10-12$ meters. These deposits consist on soft to medium stiff silty clayey soils. Proluvial deposits are less developed in the study area. They occur along the torrents and streams that run through the slopes. They have small thickness up to $2 \mathrm{~m}$ and largely consist of gravels derived by the erosion of "Rrogozhina" unit.

From the tectonic point of view the study area is part of Ardenica - Divjaka - Kryevidhi Durresi anticline chain. This chain consists of relatively quite structures, with the western flank more inclinated than the eastern one. The deposits of the eastern flank dip towards the east with $12^{\circ}-20^{\circ}$ and the ones of the western flank dip towards the west with angles $25^{\circ}-$ $30^{\circ}$ (Fig. 2.a).

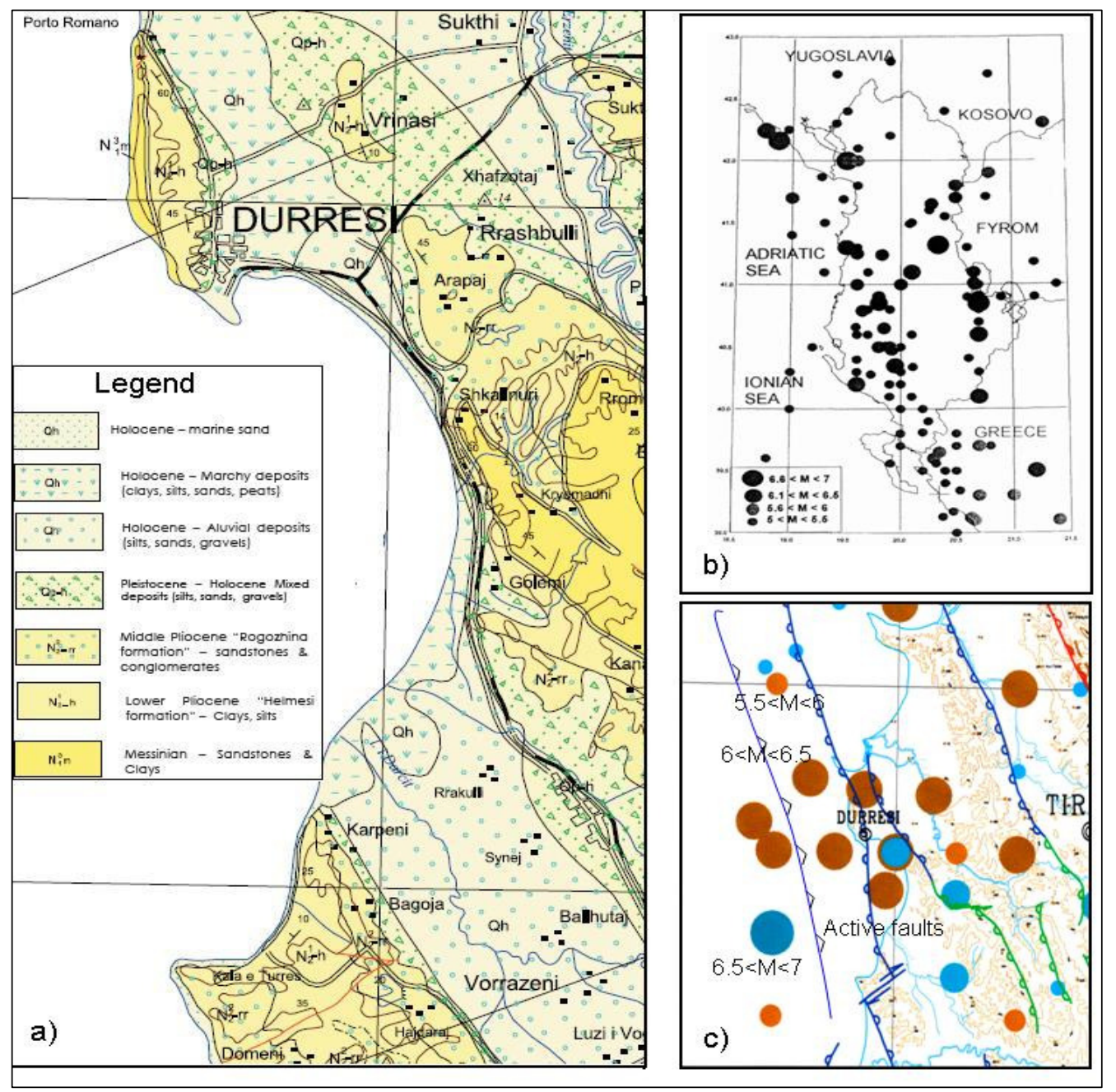

Fig. 2. a) Geological map of the study area;

b) Seismic map of Albania (years 1900-2000; M>6)

c) Earthquakes location and respective magnitudes in the study area 
At the eastern flank of the anticline structure of Kryevidhi, a fault with western dip $50^{\circ}-80^{\circ}$ and amplitude $300 \mathrm{~m}-400 \mathrm{~m}$ occurs and towards the depth it gradually vanishes. Geophysical studies indicate the presence of a second fault with amplitude up to several hundred meters at the western flank of the anticline structure of Kryevidhi. The core of the structure consists of clayey deposits of "Helmesi" unit. Clayey layers somewhere are slightly undulated.

\subsection{The seismic processes and features}

Albania is a country of a high seismicity. The seismicity of Albania is related to the contact between platform (Adria plate) and the orogeny of Albanides that in the context of the plate tectonics represents a collision contact between the Euro-asian plate and the African one. The Albanian orogeny is divided in two zones of different tectonic regime: the coastal zone, in compression, dominated by faults of northwest - southeast direction and extended like e belt $40-50 \mathrm{~km}$ wide, and the inner zone, in extension, dominated by normal faults of northern direction (Fig. 2.b, c).

The coastal zone is characterized by a regime in compression with transversal faults nearly

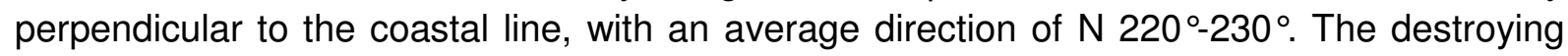
earthquakes of Durresi of the years 57, 345, 552, 1273, 1870, 1926 and many others are generated in this zone.

Based on the active faults, several main seismic zones are distinguished in Albania.

The study area is located in the lonian-Adriatic seismic zone which includes the entire PeriAdriatic Depression, from the southern margin up to Drini bay, with expected maximum magnitude of $6-6.4$ (Richter scale).

\subsection{Landslide characteristics}

The landslide characteristics are well developed in the study area. They affect almost all the types of deposits.

The formations of "Rrogozhina" unit are affected by translation and rotational slides. The depth of the sliding surfaces varies from 12 to $15 \mathrm{~m}$ (according to the geophysical data) and occurs between the weakly cemented sandstones and marly clays. Ground water circulation following this contact decrease the friction forces between the layers leading to landslides. This sliding mechanism affects more than $20 \mathrm{~m}$ and was catastrophic for Lagje Gjecaj of Synej village.

Due to the combined effect of gravity and marine wave action at the base of "Rrogozhina" unit, to the western flancs (Block 2) block slides occur.

The deposits of "Helmesi" unit, consisting mainly of plastic clays, are more affected by slumps and earth flow.

Weathering deposits, up to $10 \mathrm{~m}$ thick, are affected by earth flows, lateral spreads and creeps.

\section{Methodology}

Landslide susceptibility in the study area is estimated based in the method Frana 1-2 proposed by Riga (2008) 
This method defines the susceptibility classes compiling the weighted factors of Frana 1 and Frana 2 as follow:

$\mathrm{W}=\mathrm{W}_{1}+\mathrm{W}_{2}$

Where: $\quad W_{1}$ is the sum of weighted factors of Frana 1

$\mathrm{W}_{2}$ is the sum of weighted factors of Frana 2

The weighted factors considered in the calculation of $\mathrm{W}_{1}$ are the following:

- W1-1 - slope inclination, values ranging from -5 to +5 for slopes inclinations $<10^{\circ}$ and $>61^{\circ}$ respectively,

- W1-2 - slop shape, values ranging from -3 to +2 for concave and convex slopes respectively,

- W1-3 - vegetation, values ranging from -1 to +3 for forested areas and stripped land respectively,

- W1-4 - presence of springs, values -2 or +2 for the presence or absence of springs respectively,

- W1-5 - seismic factor, values ranging from -5 to +5 for maximal acceleration at the ground $<0.05 \mathrm{~g}$ and $>0.56 \mathrm{~g}$ respectively.

The weighted factors considered in the calculation of $\mathrm{W}_{2}$ are the following:

- $\mathrm{W}_{2-1}-$ geology, values ranging from -5 to +3 for unaltered rocks and low resistivity soils,

- $\mathrm{W}_{2-2}-$ overhang structure, values -2 or +2 ,

- $\mathrm{W}_{2-3}$ - thickness of soils, values +1 or +3 for thickness $<0.5 \mathrm{~m}$ and $>0.5 \mathrm{~m}$ respectively,

- $\mathrm{W}_{2-4}$ - fracturing, values -2 or +3 for absent or presence of fractures respectively.

Five classes of susceptibility calculated on the base of $W$ values, are given in the table 2.

Table 2. Susceptibility classes according to Frana 1-2.

\begin{tabular}{|c|c|c|}
\hline Class & Weight & Susceptibility \\
\hline A & $>6$ & High \\
\hline B & $\leq 6$ & Medium high \\
\hline C & $\leq 3$ & Medium \\
\hline D & $\leq-1$ & Medium low \\
\hline E & $\leq-4$ & Low \\
\hline
\end{tabular}

Both the "blocks" are divided in elementary cells of size $250 \mathrm{~m} \times 250 \mathrm{~m}$ for a total 455 cells, covering a surface of $28.5 \mathrm{~km}^{2}$. For each cell the class of susceptibility is carried out and the susceptibility maps are compiled at 1:10000 scale.

\section{Results and conclusions}

The following results and conclusions can be drawn from the present study.

About $35 \%$ of the study area is covered by landslides. The formations of "Rrogozhina" unit are affected by translation and rotational slides; the deposits of "Helmesi" unit, consisting 
mainly of plastic clays, are more affected by slumps and earth flow, whereas, weathering deposits up to $10 \mathrm{~m}$ thick, are affected by earth flows, lateral spreads and creeps. All the observed landslides areas correspond to the medium-high and high susceptibility classes in the maps produced by this study.

In the "Block 1", at the north of Durres City, the slopes are gentle with a maximum of $35^{\circ}$. $45 \%$ of slopes have an inclination superior of $15^{\circ}$, but only $2.7 \%$ of them have an inclination superior of $30^{\circ}$ (Fig. 3Error! Reference source not found..a).

Frana 1-2 method analysis indicate that $14 \%$ of the "Block 1 " presents high susceptibility to landslides; $36.2 \%$ medium-high susceptibility; $14 \%$ medium susceptibility and $35.7 \%$ medium-low susceptibility (Fig. 3. b). The high susceptibility is related in $84 \%$ of cases to slope inclination exceeding $20^{\circ}$, corresponding to the western part of the area and major part of them, affect the Helmesi unit dipping across the slope plane, but consisting in plastic silty clays susceptible to flows during long period of rainfalls.

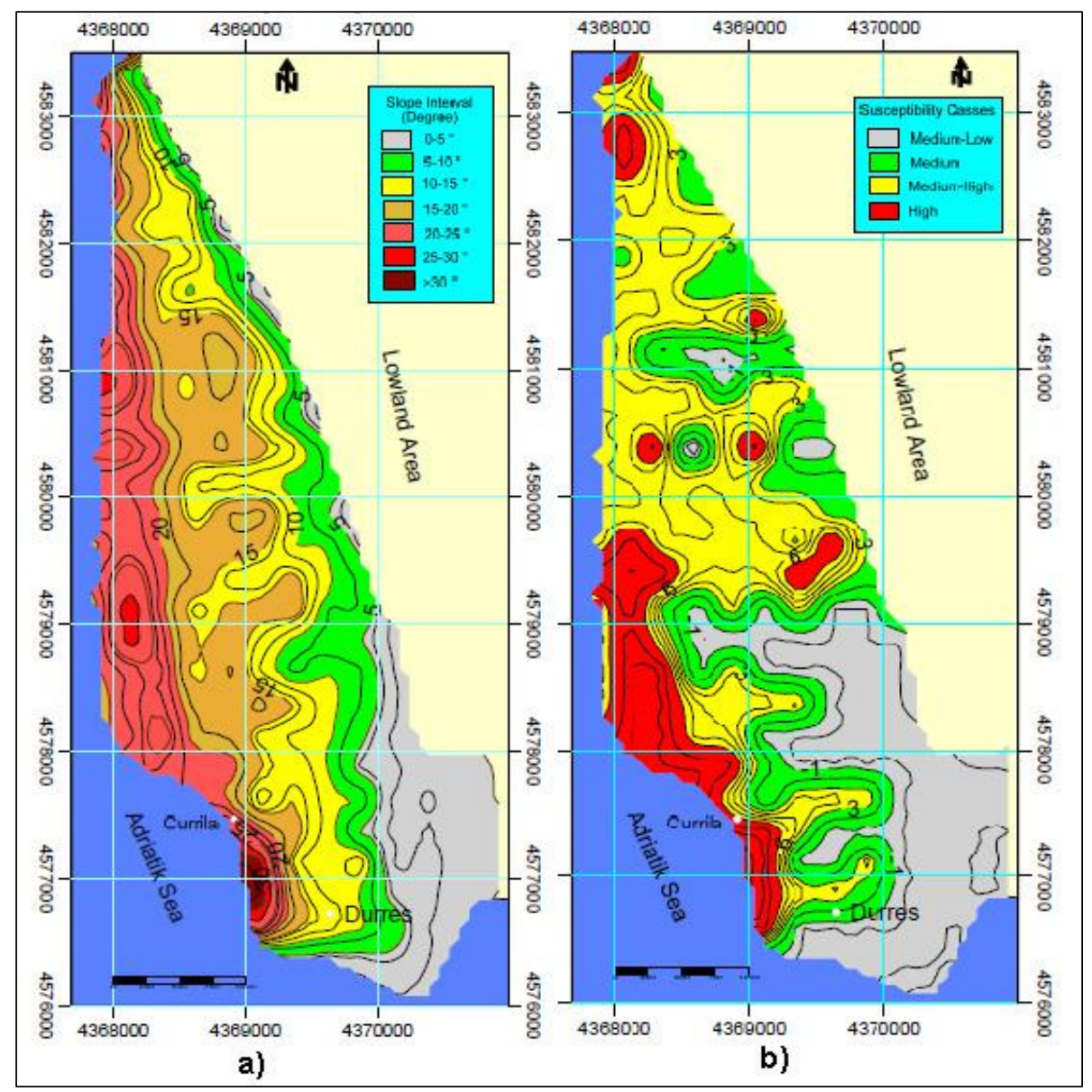

Fig. 3. Block 1. a) Slope maps of the study area; b) Susceptibility map of area In the "Block 2", $37.8 \%$ of slops have an inclination $>15^{\circ}$ and only $1.8 \%$ of them exceeds $25^{\circ}$ (Fig. 4. a).

$5.1 \%$ of "Block 2" area's represent high susceptibility to landslide; $25.5 \%$ medium-high susceptibility, $12.4 \%$ medium susceptibility, $36.6 \%$ medium-low susceptibility and $20.4 \%$ low susceptibility. $91.7 \%$ of the high susceptibility areas correspond to slope inclinations 
exceeding $15^{\circ} .72 \%$ of the medium-high susceptibility areas is related to slope inclination exceeding $15^{\circ}$ and the rest is related to slopes inclination inferior to $15^{\circ}$ (Fig. 4. b). The medium-high and high susceptibility classes are in part located in the flanks of the anticline corresponding with the Rogozhina unit dipping in the same direction as the slope, but the majority is related to the nucleus of the anticline consisting of Helmesi unit deposits.

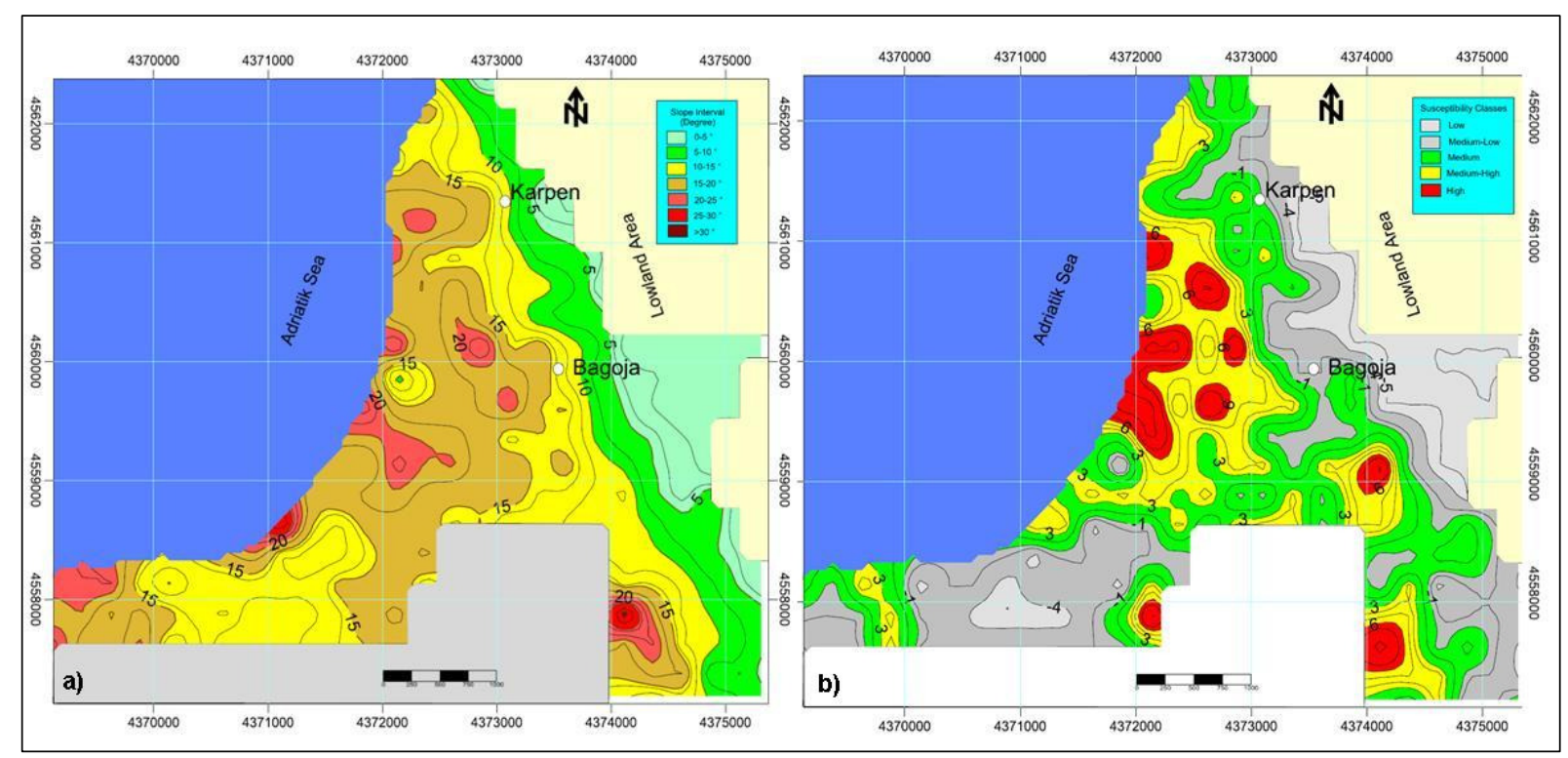

Fig. 4. Block 2. a) Slope maps of the study area; b) Susceptibility map of area

The high and medium-high susceptibility zones, in entire areas under study are controlled by slope inclination. Anyways, such zones are situated also in areas with gentle slope inclinations, du to the lithology, layering orientation vice slope inclination and anthropogenic action. Frequently, the inappropriate anthropogenic action is determinant to the rising of the susceptibility to the landslides.

\section{References}

Alcantara - Ayala, I., 2002. Geomorphology, natural hazards, vulnerability and prevention of natural disasters in developing countries. Geomorphology, 47(2): 107-124.

Aleotti, P., Chowdhury, R., 1999. Landslide hazard assessment: summary review and new perspectives. Bulletin of Engineering Geology and the Environment, 58: 21-44.

Geological Map of Albania (1:200000), 2004.

Ormeni, Rr., 2007. "The general model of construction of the Albanian earth crust and its seismoactive features according to the seismological data", PhD thesis, Polytechnic University, Tirana.

Riga, G. 2008. Microzonazione sismica. Procedure per elaborare una carta di pericolosità sismica.18 -40 .

Riga, G., 2008. Hazards - Stima del rischio sismico e del rischio di frane, D. Flaccovio Edt, Palermo.

Riga, G., 1994. Geostab - Stabilità dei pendii, Dario Flaccovio Editore, Palermo.

Sidle, R.C., and Ochiai, H., 2006. Landslides - Processes, prediction and land use: Washington D.C., American Geophysical Union, Water Resources Monograph 18, 312 p. 


\section{Littoral 2010}

TC4, Manual for zonation on seismic geotechnical hazards. Technical Committee $\mathrm{N}^{\circ} 4$, for Earthquake Geotechnical Engineering, ISSMGE, 1999. 